\title{
Factors Influencing Variation in Value and Investor Confidence
}

\author{
${ }^{1}$ Naridtanan Palakavong na Ayuthaya and ${ }^{2}$ Fredric William Swierczek \\ ${ }^{1,2}$ Faculty of Commerce and Accountancy, Thammasat University, Thailand
}

\begin{abstract}
The valuation profession is critical for the property market in emerging markets. The purpose of this study is to determine the factors that cause discrepancies in the actual value stated in valuation report. This paper included Thailand and Malaysia as representative of valuation professionals in Asian counties to perceive the effective use of valuation standards, methodologies, and processes. The commitment to ethical conduct also addressed. A comprehensive review of previous studies related to standards, process and ethical conduct of valuers in several counties were presented. The findings contribute to the perceived of importance factors which significantly affect the decrease in variation in value and increase in investor confidence. Regression analysis was used to test the hypotheses; the two dependent variables were tested including the Variation in Actual Valuation and Investor Confidence.
\end{abstract}

Keywords: Valuation, Value, Variation, Valuation Process, Ethical behaviours, Valuers, Thailand, Malaysia.

\section{Background of the Problem}

\section{Introduction}

The valuation is the most important document in the loan process. Banks require valuation for the collateral customers offer for loans. Valuation is also required for tax assessments, when the government acquires private property for public use, appraising the assets of publicly listed companies, or when financial institutions evaluate non-performing loans (NPLs). During the Asian Financial crisis in 2008, ineffective valuation practices were readily apparent. Money was lent based on grossly overvalued collateral. This exemplifies the need for professional valuation practices and an ethical approach to the behavior of valuers. This limitation resulted in improper practices in the valuation of the property sector (Brett 2010). According to Rothacker (2008) banks were pressured valuers to inflate the value of homes. This allowed lenders to offer larger loans. Price estimates were further influenced by client pressure to inflate or reduce the actual price. The main problems of valuation are gaps in the valuation process which negatively impact investor confidence, ethical issues, and the lack of enforcement of standards which reduces the effectiveness of the valuation process in Asian countries. However, Thailand and Malaysia were selected as representative countries in this study.

The research problem focuses on several major issues which are:

1. The valuation industry is growing but the attention to standards and ethics is low.

2. Discrepancies in the actual valuation negatively impacts investor confidence

3. The unethical behavior of valuer that overstates the value of a property.

4. The law and its enforcement does not support professional standards

This will determine the factors that impact on the variation in value and investor confidence of valuations in Thailand and Malaysia. The role of a property valuation law in valuation practice will be considered. Malaysia has established this law Thailand has not.

\section{Valuation Profession in Thailand}

In Thailand professional valuers and valuation firms must registered with the Valuers Association of Thailand (VAT) and Thai Valuers Association (TVA) to handle valuation projects (Bank of Thailand, 2010). The Valuers Association of Thailand (2012) lists 93 qualified valuation companies registered with both associations as of 2012. According to the current President of the Advisory Board of The Valuers Associations of Thailand the Act of Property Valuation has not yet become law (Pattanapongpiboon, 2009). The Act has been awaiting ratification since 2001. The valuation price decisions depend on individual valuer's capability to justify their valuations. Valuers independently decide on the value of a property which results in unreliable valuations. Price estimates may also be influenced by clients pressuring valuers to make a valuation based on a subjective or advantageous price.

\section{Valuation Profession in Malaysia}

Valuation in Malaysia is governed by the Valuers, Appraisers and Estate Agents Act 1981. The Act provides for the registration of valuers with the Board of Valuers, Appraisers and Estate Agents. The Act also empowers the Board to make rules relating to the profession. The Malaysian Valuation Standards, adapted from the International Valuation Standards (IVS), includes seventeen standards and two introductory chapters. The Board of Valuers, Appraisers and Estate Agents of Malaysia was established in 1981 under of the Ministry of 
Finance. Malaysian citizens or permanent residents holding relevant degrees in valuation, property management, and have passed the Test of Professional Competence conducted by the Board can be registered as a valuer in Malaysia. Only registered valuers are legally permitted to make valuations (The Board of Valuers, Appraisers and Estate Agents Malaysia, 2010; Sui, 2001).

\section{Literature Review}

A search for citations related to property valuation shows limited comprehensive reviews of literature. Hordijk, et al., (2011) have compared standards across countries and indicate that valuation standards as usually applied are country specific. Another study on the importance of a legal framework on valuation practices showed that valuations often did not reflect actual market value because of the valuers actions not legal requirements. Based on past research and practical experience, the relevant topics considered in this review of literature include the valuation process, valuation standards, ethics of valuer, client influence, enforcement, variation in value, and investor confidence (Gilbertson and Preston, 2005).

\section{Valuation Process}

The valuation process relates to the actions taken to determine valuation outcomes. An assessment of the valuation process is essential because many factors can assert influence. The unethical conduct of valuers can deliberately bias valuation outcomes. The valuation process relies on the personal knowledge and expertise of the valuer. Avittey, et al., (2006) identified 6 main steps concerning the valuation process. These included specifying the property legally and physically, the property rights related to the current estimate, the purpose of the valuation and the valuation date. Comparative market data is then gathered in which the skill, knowledge, and experience of the valuer become essential. The final step is to apply appropriate methods and techniques to derive the estimated value (Avittey, et al., 2006). An independent review found that $90 \%$ of appraisers felt pressured to change property valuations to enable deals to go through (Forsythe Appraisals, 2008). The only independent party in a mortgage transaction is the appraisers and they gain no direct benefit from raising or lowering the valuation of a property. The study also pointed out the need for strict enforcement.

Recent research indicates that appraisers are being pressured by Banks to inflate the value of homes (Rothacker, 2008). This allows lenders to make bigger loans. Fannie Mae and Freddie Mac created a new independent oversight body and code of conduct to remove undue influence from the valuation process (Forsythe Appraisals, 2008). Appraisers unfamiliar with a specific market were influenced by previous value judgments and by their previous appraisal experience (Yiu, et al., 2006). Experienced appraisers adopt an appraisal process that differs from that specified in legal standards. They use assumptions more than proven indicators (Lin and Chang (2012). An accurate valuation process relies extensively on personal knowledge, expertise, and interpretation of many variables in valuation methods which could influence the assessment (Hager and Lord, 1985). Valuers need to understand the dynamics of the potential purchasers, the demand, and the competition for each property to accurately assess the property's value (Harper, 2008). With a better process valuers would have a more effective valuation. Risk and uncertainty are inherent parts of the valuation process. The valuer is often unable to specify and price accurately all current and future influences on the value of an asset. The valuer must manage the risk analysis within the valuation process to minimize negative consequences and to establish confidence for the end user (Adair and Hutchison, 2005).

\section{Valuation Standards}

There is limited research on comparative valuation standards. These studies were conducted mostly in European countries which have valuation standards established for many years. They consider the methods of valuation, the development of computerized mass appraisal systems for valuation, and the necessity for the adoption of more effective valuation practices. Tighter appraisal standards identify poor evaluators (Miller, 2011). Mansfield and Royston (2007) studied Valuation practice in Czech Republic, Hungary and Poland. They found valuations do not match the internationally recognized definitions of 'market value' provided by IVSC. There is a recognized need for consistency in the application of valuation practices. Lorenz, et al. (2006) stated that universal property valuation does not exist because some methods may be more applicable than others depending on the context. Superior valuations are not necessarily associated with mathematical precision. Differences include how valuers express their assumptions, account for risk and uncertainties, and communicate the results of the estimation process to the end user.

Another issue is to increase standardization. The International Valuation Standards (IVSC) promote the development of the valuation profession around the world and cooperates with other organizations concerned with standards and regulation in the financial market, the latest revised version is 2011 (Thorne, 2012). French (2011) states the intent of the RICS Standards is not to penalize but to encourage and promote good practices. Hordijk, et al. (2011) investigated valuation practices in France, Germany, Italy, Netherlands, Portugal, Russia, Spain, and UK. In different countries market value is not always the basis of a valuation. Although market 
values can be compared across countries, valuation methodologies are country-specific. Countries such as Hong Kong and Malaysia apply the standard of the Royal Institute of Chartered Surveyors (RICS) (Thapanachai, 2008). Korea, Philippines, and Thailand established universally accepted local standards based in RICS and IVSC. Valuers need only a government issued license to practice valuation in those countries. International investor confidence is low regarding the reliability and integrity of the actual value stated in valuation reports (Hummel, 2008; Thapanachai, 2008).

\section{Ethics of the Valuer}

Unethical conduct leads to discrepancies in valuation value lost investor confidence and the potential loss of investment in real estate (Business and Social Sciences Review, 2011). Professional appraisers are less likely to misreport when organization rules are strictly enforced. Markets which have experienced financial scandals are required by regulators and stakeholders to improve their code of ethics. Many investors are especially concerned for business ethics because of the positive effect on financial performance (Dominguez, et al., 2009). Levy and Schuck (1999) claimed an unethical valuer will change the reported value beyond the original range of defensible values even if the client has not influenced their estimate of the property's value. According to Joslin (2005) individual valuers must assess uncertainty and offer the client what they feel is their best price estimate. The valuers must consider the client's appropriate needs and recognize the importance of the valuation, and the factors that impact the valuation. Unethical conduct in property valuation is rendering a value estimate that accommodates the requirements of a specific client instead of one that is impartial, objective, and independent (Amidu and Aluko (2007).

Other ethical issues involved with performing valuations relates to lenders that are more interested in inflated valuations than unbiased and objective findings (Rushmore, 1993). Hoyt, et al. (2002) examined the ethical values of registered valuers in New Zealand. Results indicate that the differences between registered valuers' beliefs and ethical values were based upon differences in demographic factors such as age, gender, education, type of work performed and valuation experience, and whether they had taken a professional ethics course or not. The measurement of value will vary from valuer to valuer, although the procedures are undertaken in the same way (Warren-Myers and Heywood, 2010). Violations of the ethics should be punished (Layne, 2002).

\section{Client Influence}

Research on client influence documents the valuation bias or the negative influence on appraisals. There are a range of issues concerning the type and size of clients and their influence on valuations. Amidu and Aluko (2007) identified the factors determining the extent of client influence on estate surveyors and valuers. They found two major factors: the valuer and valuation firm's characteristics and the client characteristics. Influence was mostly from borrowers as bank and financial institutions customers, a vendor and purchaser as buyers and sellers of property in the market (Amidu and Aliko, 2007). Client influence on the final reported value results from the negotiation between valuers and clients (Chen and $\mathrm{Yu}, 2009$ ). The degree of client influence on valuations relates to the type of client, the characteristics of valuers and valuation firms, the purpose of a valuation and the information power of clients and valuers (Levy and Schuck, 1999). The findings showed;

1. Bankers exert a negative pressure on a final valuation figure

2. Developers, the most difficult type of client to manage, pressured valuers to report inflated values for funding purposes

3. Fund managers often request a conservative valuation (Levy and Schuck, 1999).

Unethical valuation firms tended to be medium or smaller sized firms servicing a less sophisticated clientele (Levy and Schuck, 1999). Clients with expertise and a high level of knowledge of the property market are able to influence valuers (Levy and Schuck, 2005). 60\% of UK valuers agree to increase their valuation if external parties exerted pressure during the process (Bretten and Wyatt, 2002). Chang (2004) concluded that clients who are familiar with the valuation industry may use business pressure, changing the valuation purpose, providing transaction data, giving land development and architecture know-how, and financial expertise to influence valuers. Whereas, clients who lack familiarity with the valuation industry tend to use business pressure to threaten valuers (Chang, 2004). Smolen and Hambleton (1997) found that most certified appraisers agreed that appraisers are pressured by clients to alter their values. Client influence can increase by the control they have over the valuation process. New Zealand permits clients to review draft valuations prior to formalization during a draft review customers may influence the final valuation results (Levy and Schuck, 2005).

\section{Enforcement}

Current research is limited on the enforcement of valuation standards and ethical conduct despite the importance of enforcement in the valuation process. A survey on compliance to ethical norms of property 
valuers emphasized the application of penalties for violating professional ethics regulations of for property valuers. Penalties include formal caution, note of warning, suspension of certification, and certificate withdrawal. Vitell (2006) studied the effect of ethical values and enforcement of ethical conduct on the overall success of American and Spanish valuation firms. The findings indicate American valuers have significantly higher ethical values and enforcement than their Spanish peers.

Cao (2009) explained that the Chinese central government cannot control the behavior of local authorities. As a result there is little enforcement of laws to have accurate valuations to improve the ethical conduct of valuation in the Chinese market. In the United States, as a result of a criminal investigation a real estate appraiser from Los Angeles was jaded and ordered to pay more than $\$ 46$ million in restitution. The US government warned that other professional real estate appraisers should know that if they inflate appraisals and misrepresent the value of homes, likely they will be apprehended and sentenced to prison (U.S. Attorney's Office, 2010). Enforcement is critical for actual variation and investor confidence.

\section{Variation in Value}

Actual valuation is the appraisal outcome reported to investors. The valuation outcomes are estimated in the valuation process. Several studies show that the actual valuation reports often overstate value because of the unethical behavior of valuers. The literature indicates that the lack of reliability in actual valuation leads to a loss of investor confidence. Appraisers tend to overstate the value of a property because of their incentive to set the appraised value to be equal to or greater than the transaction price (Gwin and Maxam, 2002). 98\% of American valuers provided higher valuation values because of incentives in a boom market (Smith, 2002). Pacharavanich and Rossini (2001) found that the appraisal value exceeded the declared price in $81 \%$ of 40 residential condominium projects.

Bretten and Wyatt (2001) found that the client, the property, the instructions, the value, and the firm are the possible causes of valuation variance. They determined that the valuers' behavioral influence is a major cause of variance. Valuation varies from valuer to valuer (Joslin, 2005). Levy and Schuck (1999) observed different values may be estimated for the same property because of different assumptions. Valuer knowledge and experience, the approach to valuation, and the characteristics of valuers and valuation firms are significant influences on valuation accuracy (Babawale and Omirin (2012). In Spain ${ }_{2}$ the residential property market found valuation differences within a range of plus or minus $15 \%$ and a tendency to_over-value rather than under_value (McGreal and Taltavull de La Paz, 2012). Ten different valuers may produce ten different interpretations (Whipple, 1990:160). Gallimore (1994, 1996) has found significant valuer biases across types of property valuations. An acceptable of variation in actual value is around plus or minus 10\% to 15\% (Baum et al., 2000).

\section{Investor Confidence}

Real estate investment and development relies on valuation results. Advice from the valuation professionals is important to the investment decision. Kauko and Amato (2009) determined that the accuracy of the property valuation system could increase investor confidence in financial real estate assets. For institutional investors the commercial valuation report is a key for decision making in property investment (Business and Social Sciences Review, 2011). Gallimore and Gray (2002) conducted a survey on 218 property investment decision makers in the UK found that positive investor sentiment, including views of professional valuers, is an important factor in making property investment decisions. Property valuation assessments and feasibility studies are significant drivers in real estate investment and development decision making (Farrelly and Sanderson, 2005). Executive decisions are typically based on advice from valuation professionals (Mansfield, 2009). Razali and Adnan (2012) found Malaysian property companies have high transparency which increases investor confidence and attracts more investors in the property market.

\section{Methodology}

A survey was used to gather data from three relevant groups of respondents: managing directors and professional valuers of valuation firms, valuation department managers from banks, and investors in Thailand and Malaysia. The survey was designed based on the literature review and the conceptual model. Questions were focused on evaluating the effectiveness of current valuation standards and process and the ethical conduct of valuers in the property valuation profession in Thailand and Malaysia. Indicators are measured by using a 1-5 point scale. The survey questionnaire begins with instructions for answering each set of questions. The questionnaire is divided into 3 main sections: Sections A and B comprise 80 questions on valuation standards and the ethics of valuers. Section C contains 10 questions on the background information of the respondents. The data was collected from 181 respondents in Thailand and 98 respondents in Malaysia from 3 samples; valuers, bankers, and investors. Regression analysis was used to test the hypotheses. Two dependent variables were tested including the Variation in Actual Valuation and Investor Confidence. 12 independent variables were used to determine how much of an impact on the dependant variable is explained. The beta coefficient was used 
to show the relationship between each independent variable and the dependent variables. The level of variance explained by the independent variables in Variation in Actual Valuation and Investor Confidence was determined by the $\mathrm{R}^{2}$.

\section{Research Model}

Two research models are designed for Variation in Actual Valuation and Investor Confidence. Each model includes three major dimensions. Report and Valuer Quality, the Valuation Process and Impacts (Figures 4.1, 4.2). Multiple Correlation analysis is used to examine the key relationships in each model (Figures 5.1, 5.2)

\section{Reverse Scoring}

The process of reversing the score of a variable for example from $5=$ High to $5=$ Low returns the characteristics of the distribution but changes the relation between two variables (Hair et al, 2010: 93). Data values are reversed so that its correlations with other variables go from negative to positive indicating that the higher the level of the IV, the lower the level of DV. (Hair et al, 2010: 126). In this research the relevant DV is Variation in Value $5=$ Low the better the valuer's conduct, the lower the variation in value. Another variable is reversed is the IV Client Influence in this case $5=$ Lowest Client. This means that Lower Client Influence relates to Less Variation in value.

\section{Summary of Factor Means Scores Reverse Scoring}

Table 4.1 Summary of Variables

\begin{tabular}{|l|r|r|}
\hline \multicolumn{1}{|c|}{ Variables } & \multicolumn{1}{c|}{ Mean } & Std. Deviation \\
\cline { 2 - 3 } & \multicolumn{1}{c|}{ Valid } & \multicolumn{1}{c|}{ Missing } \\
\hline Valuation Purpose & 4.26 & 0.57 \\
Complete Report & 4.40 & 0.59 \\
Scope and Assumptions & 4.34 & 0.57 \\
Role of Valuer & 4.33 & 0.50 \\
Valuer Qualification & 4.07 & 0.62 \\
Written Confirmation & 3.79 & 0.82 \\
Valuer Conduct & 4.76 & 0.46 \\
Enforcement & 4.39 & 0.71 \\
Disclosure & 4.56 & 0.49 \\
Variation in Value & 1.20 & 0.73 \\
Investor Confidence & 3.90 & 0.81 \\
Level of Conflict of Interest & 4.47 & 0.64 \\
Level of Influence from Client & 1.32 & 0.78 \\
\hline
\end{tabular}

Table 4.1 reports the mean score of each new variable in both Valuation Standards and Ethical Behavior based on factors analysis. The mean scores were selected from all valuers, bankers, and investors both from Thailand and Malaysia. These 13 variables would significantly decrease variation in value and increase investor confidence. Most variables had high mean scores indicating the respondents considered these factors were important for valuation outcomes.

Variation in value * (Reversed) 3.80

Level of Influence from Client * (Reversed) 3.68

$*$ Low $=5$, High $=1$

Source: Jaccard and Turrisi (2003).

\section{Multiple Correlations}

Table 4.2 Correlations

\begin{tabular}{|c|c|c|c|c|c|c|c|c|c|c|c|c|c|}
\hline \multicolumn{14}{|c|}{ Multiple Correlations - All Variables } \\
\hline & 1 & 2 & 3 & 4 & 5 & 6 & 7 & 8 & 9 & 10 & 11 & 12 & 13 \\
\hline \multirow{2}{*}{$\begin{array}{l}1 . \\
\text { Valuation } \\
\text { purpose }\end{array}$} & 1 & $.488(* *)$ & $.568(* *)$ & $.4266^{(* *)}$ & $.307(* *)$ & $.364(* *)$ & $.369^{(* *)}$ & .023 & $.427(* *)$ & $.203(* *)$ & $.170^{(* *)}$ & $.410(* *)$ & -.071 \\
\hline & . & .000 & .000 & . 000 & . .000 & .000 & . 000 & .708 & .000 & .001 & . 005 & . 000 & .239 \\
\hline \multirow{2}{*}{$\begin{array}{l}2 . \\
\text { Report } \\
\text { Completion }\end{array}$} & $.488(* *)$ & 1 & $.388(* *)$ & $.3711^{(* *)}$ & $.448(* *)$ & $.363(* *)$ & $.423(* *)$ & .084 & $.591(* *)$ & $.481(* *)$ & $.323(* *)$ & $.437(* *)$ & .051 \\
\hline & .000 & . & .000 & .000 & .000 & .000 & .000 & .166 & .000 & .000 & .000 & .000 & .397 \\
\hline \multirow{2}{*}{$\begin{array}{l}3 . \\
\text { Scope and } \\
\text { Assumptions }\end{array}$} & $.568(* *)$ & $.388(* *)$ & 1 & $.567(* *)$ & $.316(* *)$ & $.369(* *)$ & $.364(* *)$ & $.192(* *)$ & $.367(* *)$ & .117 & -.055 & $.346(* *)$ & -.035 \\
\hline & .000 & .000 & & .000 & .000 & .000 & .000 & .001 & .000 & .052 & .360 & .000 & .569 \\
\hline \multirow{2}{*}{$\begin{array}{l}4 . \\
\text { Role of Valuer }\end{array}$} & $.426(* *)$ & $.371(* *)$ & $.567(* *)$ & 1 & $.327(* *)$ & $.442(* *)$ & $.331(* *)$ & $.343(* *)$ & $.284(* *)$ & .088 & $\begin{array}{l}.052 \\
\end{array}$ & $.299(* *)$ & .007 \\
\hline & .000 & .000 & .000 & & .000 & .000 & .000 & .000 & .000 & .147 & .392 & .000 & .913 \\
\hline \multirow{2}{*}{$\begin{array}{l}5 . \\
\text { Valuer } \\
\text { Qualification }\end{array}$} & $.307(* *)$ & $.448(* *)$ & $.316(* *)$ & $.327(* *)$ & 1 & $.550^{(* *)}$ & $.1955^{(* *)}$ & $.255(* *)$ & $.468(* *)$ & $.399^{(* *)}$ & $.344(* *)$ & $.371(* *)$ & $.2211^{(* *)}$ \\
\hline & .000 & .000 & .000 & .000 & & .000 & .001 & .000 & .000 & .000 & .000 & .000 & .000 \\
\hline \multirow{2}{*}{$\begin{array}{l}6 . \\
\text { Written } \\
\text { Confirmation }\end{array}$} & $.364(* *)$ & $.363(* *)$ & $.369(* *)$ & $.442(* *)$ & $.550(* *)$ & 1 & $.192(* *)$ & $.223(* *)$ & $.387(* *)$ & $.307(* *)$ & $.1799^{(* *)}$ & $.260(* *)$ & $\begin{array}{l}.033 \\
\end{array}$ \\
\hline & .000 & .000 & .000 & .000 & .000 & & .001 & .000 & .000 & .000 & .003 & .000 & .586 \\
\hline
\end{tabular}




\begin{tabular}{|c|c|c|c|c|c|c|c|c|c|c|c|c|c|}
\hline \multicolumn{14}{|c|}{ Multiple Correlations - All Variables } \\
\hline & 1 & 2 & 3 & 4 & 5 & 6 & 7 & 8 & 9 & 10 & 11 & 12 & 13 \\
\hline \multirow{2}{*}{$\begin{array}{l}7 . \\
\text { Valuer } \\
\text { Conduct }\end{array}$} & $.369(* *)$ & $.423(* *)$ & $.364(* *)$ & $.331(* *)$ & $.195(* *)$ & $.192(* *)$ & 1 & $.220(* *)$ & $.389(* *)$ & $.193(* *)$ & $.221(* *)$ & $.466(* *)$ & -.033 \\
\hline & .000 & .000 & .000 & .000 & .001 & .001 & . & .000 & .000 & .001 & .000 & .000 & .583 \\
\hline \multirow{2}{*}{$\begin{array}{l}8 . \\
\text { Enforcement/ } \\
\text { Violation }\end{array}$} & .023 & .084 & $.192(* *)$ & $.343(* *)$ & $.255(* *)$ & $.223(* *)$ & $.220(* *)$ & 1 & $\left..1311^{*}\right)$ & .099 & .001 & $.1666^{(* *)}$ & $.122(*)$ \\
\hline & .708 & .166 & .001 & .000 & .000 & .000 & .000 & & .030 & .099 & .990 & .006 & .043 \\
\hline \multirow{2}{*}{$\begin{array}{l}9 . \\
\text { Disclosure }\end{array}$} & $.427(* *)$ & $.591(* *)$ & $.367(* *)$ & $.284(* *)$ & $.468(* *)$ & $.387(* *)$ & $.389(* *)$ & $.131(*)$ & 1 & $.413(* *)$ & $.308(* *)$ & $.459(* *)$ & .088 \\
\hline & .000 & .000 & .000 & .000 & .000 & .000 & .000 & .030 & . & .000 & .000 & .000 & .142 \\
\hline \multirow{2}{*}{$\begin{array}{l}10 . \\
\text { Variation in } \\
\text { Value }\end{array}$} & $.203(* *)$ & $.481(* *)$ & .117 & .088 & $.399(* *)$ & $.307(* *)$ & $.193(* *)$ & .099 & $.413(* *)$ & 1 & $.416(* *)$ & $.317(* *)$ & $.348(* *)$ \\
\hline & .001 & .000 & .052 & .147 & .000 & .000 & .001 & .099 & .000 & & .000 & .000 & .000 \\
\hline \multirow{2}{*}{$\begin{array}{l}11 . \\
\text { Investor } \\
\text { Confidence }\end{array}$} & $\left..170^{* * *}\right)$ & $.323(* *)$ & -.055 & -.052 & $.344(* *)$ & $.179(* *)$ & $.221(* *)$ & .001 & $.308(* *)$ & $.416(* *)$ & 1 & $.299(* *)$ & $.1999^{(* *)}$ \\
\hline & .005 & .000 & .360 & .392 & .000 & .003 & .000 & .990 & .000 & .000 & & .000 & .001 \\
\hline \multirow{2}{*}{$\begin{array}{l}12 . \\
\text { Conflict } \\
\text { of Interest }\end{array}$} & $.410(* *)$ & $.437(* *)$ & $.346(* *)$ & $.299(* *)$ & $.371(* *)$ & $.260(* *)$ & $.466(* *)$ & $.166\left(^{(* *)}\right.$ & $.459(* *)$ & $.317(* *)$ & $.299(* *)$ & 1 & .106 \\
\hline & .000 & .000 & .000 & .000 & .000 & .000 & .000 & .006 & .000 & .000 & .000 & & .079 \\
\hline \multirow{2}{*}{$\begin{array}{l}13 . \\
\text { Influence } \\
\text { from Client }\end{array}$} & -.071 & .051 & -.035 & .007 & $.221(* *)$ & .033 & -.033 & $.122(*)$ & .088 & $.348(* *)$ & $.199^{(* *)}$ & .106 & 1 \\
\hline & .239 & .397 & .569 & .913 & .000 & .586 & .583 & .043 & .142 & .000 & .001 & .079 & . \\
\hline
\end{tabular}

** Correlation is significant at the 0.01 level (2-tailed)

* Correlation is significant at the 0.05 level (2-tailed).

The correlations shown in Table 4.2 reported the significant relationship between the 13 factors. Valuer Qualification was found significantly related to all other 12 factors. Follow by Written Confirmation, Valuer Conduct and Disclosure 11 significant relationship were found among these factors. However, Influence from Client was found not many correlated with other factors only 4 factors were positively correlated. Report Completion and Disclosure were found highest correlated $(.59, \mathrm{p}<.001)$. Valuation Purpose with Scope and Assumption were strongly correlated $(.56, \mathrm{p}<.001)$ Also, Scope and Assumption with Role of Valuer $(.56, \mathrm{p}<$ $.001)$.

\section{Proposed Research Model 1: Variation in Value}

Figure 4.1 Proposed Research Model 1: Variation in Value

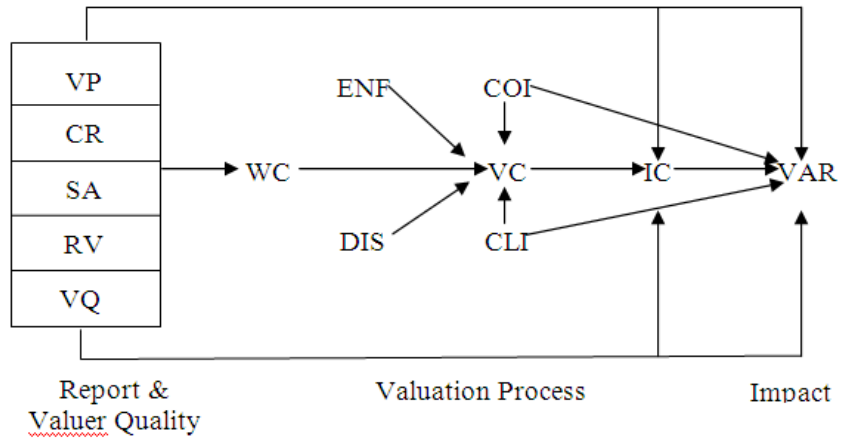

Proposed Research Model 2: Investor Confidence

Figure 4.2 Proposed Research Model 2: Investor Confidence

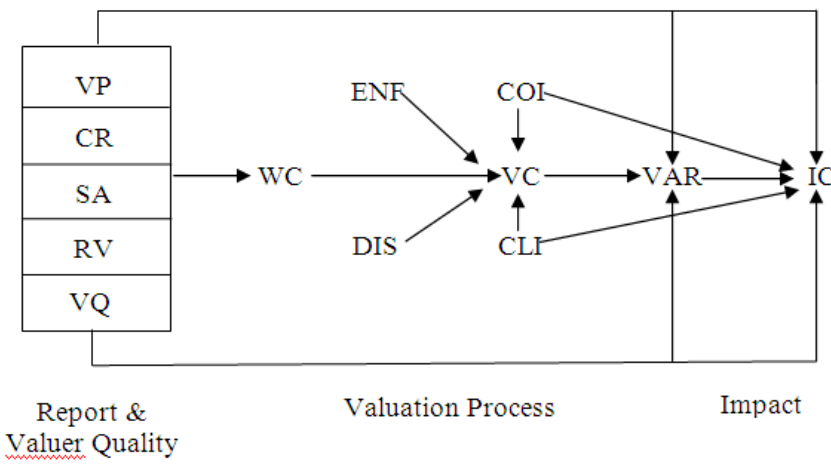




\section{Results}

\section{Model 1 Results}

Figure 5.1 Model 1 Results

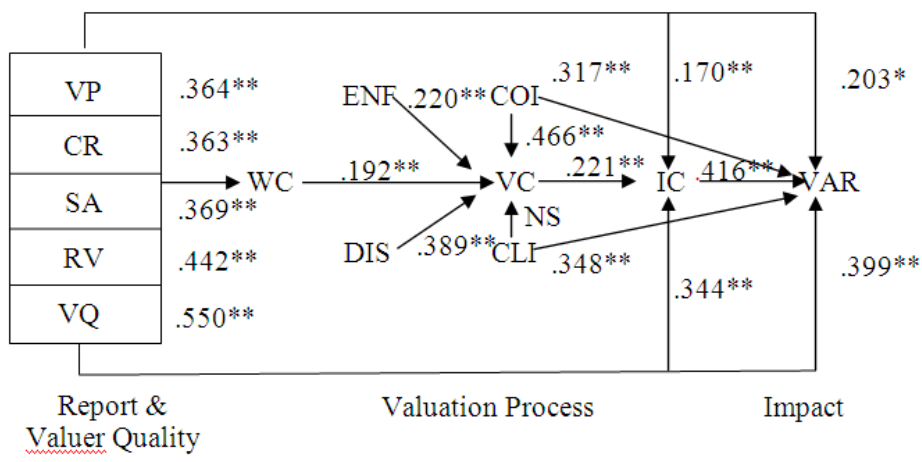

Model 1 reviews the relationships of the Independent variables with the decrease in Variation. This analysis indicates an important pattern. Report \& Valuer Quality factors; Valuation Purpose (VP), Complete Report (CR), Scope and Assumption (SA), Role of Valuer (RV) and Valuer Qualification (VQ) significantly relate to Written Confirmation (WC). Also, Written Confirmation, Enforcement (ENF), Conflict of Interest (COI) and Disclosure (DIS) positively relate to Valuer Conduct (VC) these factors are the Valuation Process Factors. In turn The Valuer Conduct relates to Investor Confidence (IC) at .221 and Investor Confidence strongly correlated to Variation in Value (VAR) at .461. Besides, Conflict of Interest (.317) and Client Influence (.348) significantly relate to Variation. These results support the importance of a formal approach to valuation as well as specific terms of reference for the Valuer. This combination will reduce the variations in the valuation estimates.

\section{Model 2 Results}

Figure 5.2 Model 2 Results

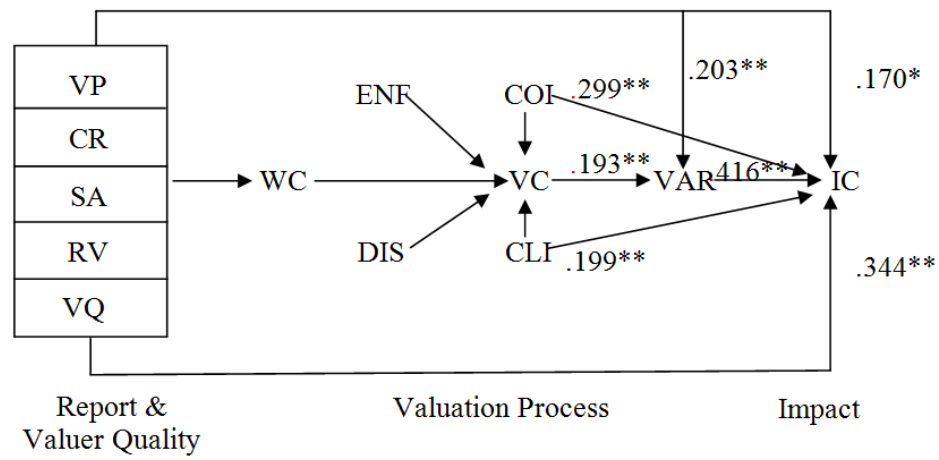

Model 2 considers the inter correlations between the independent variables including Variation in Value with Investor Confidence. This model has a similar pattern for factors related to Report and Valuer Quality. The Valuer Conduct significantly relates to Variation in Value (.193) and Variation in Value also positively relates to Investor Confidence (.416). The Level of Conflicts of Interest (.299) and Level of Client Influence (.199) relate to Investor Confidence. The implication of this model is that Investor Confidence is very influenced by the Process of valuation including Valuation Purpose and Scope and Assumptions as well as the behavior of the valuer.

\section{Hypotheses Testing}

Twelve independent variables were used to explain the impact on the dependant variable to test hypotheses in Table 5.1 and 5.2. The beta coefficient shows the relationship between each independent variable and the dependent variables. The level of each dependent variable was explained by the influence of the twelve independent variables as shown in $\mathrm{R}^{2}$. 


\section{Hypothesis: Variation in Value}

Table 5.1Hypothesis: Variation in Value

\begin{tabular}{|l|l|}
\hline H1: & Better valuation purpose significantly decrease the variation in value \\
\hline H2: & Better complete report significantly decreases the variation in value \\
\hline H3: & Better scope and assumptions significantly decreases the variation in value \\
\hline H4: & Better role of valuer significantly decreases the variation in value \\
\hline H5: & Better valuer qualification significantly decreases the variation in value \\
\hline H6: & Better written confirmation significantly decreases the variation in value \\
\hline H7: & Appropriate valuer conduct significantly decreases the variation in value \\
\hline H8: & Better enforcement significantly decreases the variation in value \\
\hline H9: & Appropriate disclosure significantly decreases the variation in value \\
\hline H10: & Less conflict of interest significantly decreases the variation in value \\
\hline H11: & Less client influence significantly decreases the variation in value \\
\hline H12: & More investor confidence significantly decreases the variation in value \\
\hline
\end{tabular}

A total of 12 hypotheses in Table 5.1 are proposed from the factor analysis. Variation in Value as dependent variables will be used to test. The level of significance factor is accepted at 0.05 or below.

\section{Hypothesis: Investor Confidence}

Table 5.2 Hypothesis: Investor Confidence

\begin{tabular}{|l|l|}
\hline H13: & Better valuation purpose significantly increase investor confidence \\
\hline H14: & Better Complete Report significantly increase investor confidence \\
\hline H15: & Better scope and assumptions significantly increase investor confidence \\
\hline H16: & Better role of valuer significantly increase investor confidence \\
\hline H17: & Better valuer qualification significantly increase investor confidence \\
\hline H18: & Better written confirmation significantly increase investor confidence \\
\hline H19: & Appropriate valuer conduct significantly increase investor confidence \\
\hline H20: & Better enforcement significantly increase investor confidence \\
\hline H21: & Appropriate disclosure significantly increase investor confidence \\
\hline H23: & Less conflict of interest significantly increase investor confidence \\
\hline H24: & Less client influence significantly increase investor confidence \\
\hline H22: & Less variation in value significantly increase investor confidence \\
\hline
\end{tabular}

A total of 12 hypotheses in Table 5.2 (H13 to H22) are proposed from the analysis factor. Investor Confidence as dependent variables will be used to test. The level of significance factor is accepted at 0.05 or below.

\section{Regression Analysis: Variation in Value}

Table 5.3 Dependent Variable: Variation in Value

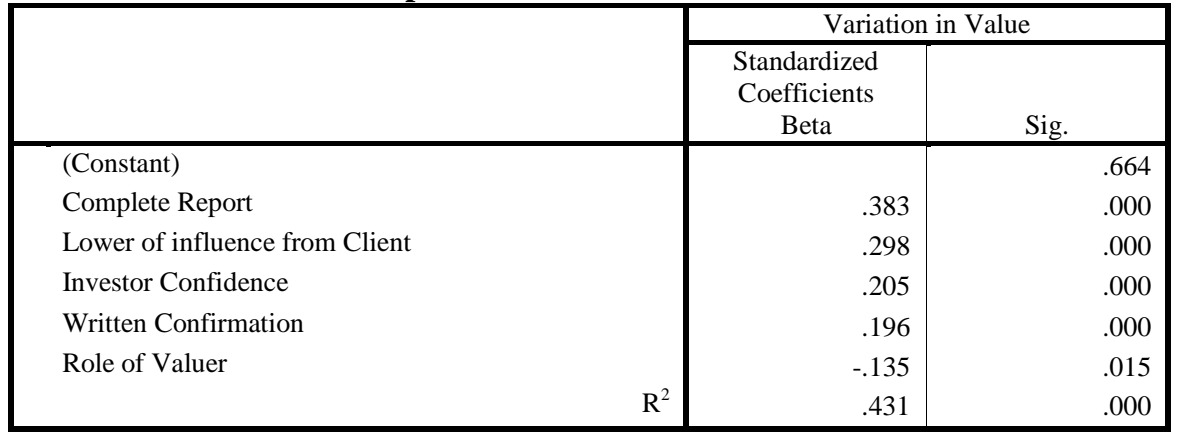

Table 5.3 presents Model for Variation in Value. The model achieves predictive accuracy with an $\mathrm{R}^{2}$ of 43\%. There were five significant variables: Complete Report, Level of Influence from Client, Investor Confidence, Written Confirmation, and Role of Valuer. Complete Report had the strongest influence with a .383 standardized coefficients beta.

A Complete Report is a significantly positive influence on variation in value. Influence from Client, Investor Confidence, and Written Confirmation were also positive influences on variation in value. Complete Report, Level of Client Influence, and Written Confirmation significantly decrease variation in actual valuation. Role of Valuer negatively impacts variation in value. The main reason for this negative impact is because the valuer conducting the valuation relies more on subjectivity than the objective standards also, best practice and external factors influence more. Individual valuers differ which results in the negatively influence of the Role of Valuer on Variation in Value (Somsuk, et al., 2012). 


\section{Regression Analysis: Investor Confidence}

Table 5.4 Dependent Variable: Investor Confidence

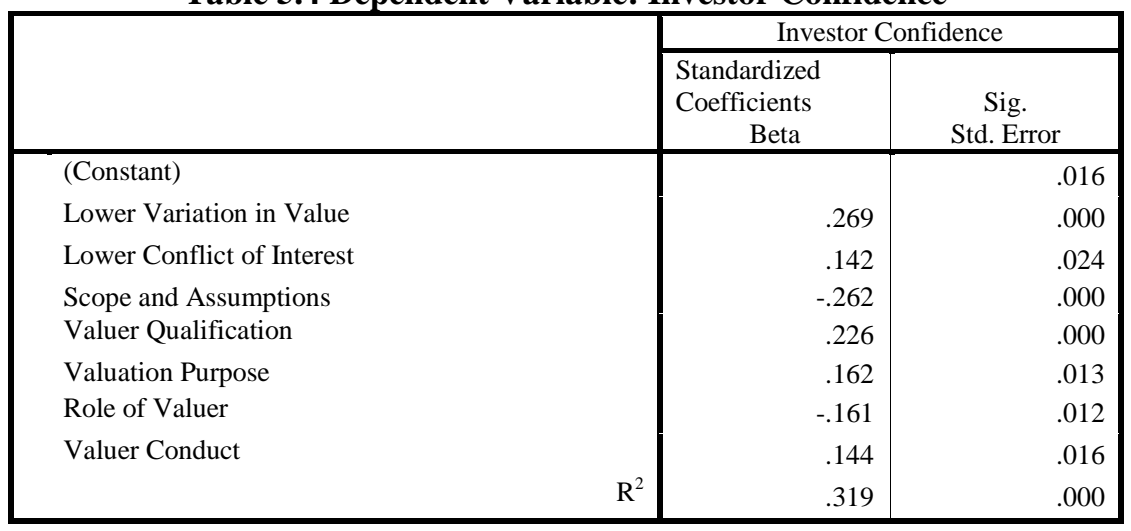

Table 5.4 shows the second regression model results for Investor Confidence. The model achieves a predictive accuracy with $31 \%$ of variance explained. There were seven significant variables: Variation in Value, Level of Conflict of Interest, Scope and Assumptions, Valuer Qualification, Valuation Purpose, Role of Valuer, and Valuer Conduct. The two major influences were Lower of Variation in Value with a 269 beta coefficient and Valuer Qualification (.226), Valuation Purpose (.162) and Valuer Conduct (.144).

This indicates that better valuer qualifications and low of variation in value significantly increase investor confidence. Valuation purpose, valuer conduct, and level of conflict of interest also positively influence investor confidence. Level of variation in value, valuer qualification, valuation purpose, valuer conduct, and level of conflict of interest significantly increase investor confidence. However, scope and assumptions and role of valuer negatively impact investor confidence claimed in an interview that the reason for The scope and assumptions negatively impact on investor confidence due to external factors such as social, economy, and politic pressures that are not included or mentioned in the conditions and assumptions stated in the valuation report. For the role of valuer, the reason is most likely similar to the dependent variable level of Variation in Value because valuers relied heavily on their personal judgments rather than the standards when conducting valuations. Since there is no law or enforcement in Thailand, Role of Valuer negatively influences investor confidence. Another reason is investor confidence relies more on institutional and company reputation than the reputation of individual valuers. The investors relied more on their knowledge and experience than the values provided by the valuer (Somsuk, et al., 2012).

\section{Summary of Hypothesis: Decrease Variation in Value}

Table 5.5 Summary of Hypothesis: Decrease Variation in Value

\begin{tabular}{|l|l|c|c|}
\hline H1: & Better valuation purpose significantly decrease the variation in value & NS & Reject \\
\hline H2: & Better complete report significantly decreases the variation in value & .383 & Accept \\
\hline H3: & Better scope and assumptions significantly decreases the variation in value & NS & Reject \\
\hline H4: & Better role of valuer significantly decreases the variation in value & -.135 & Reject \\
\hline H5: & Better valuer qualification significantly decreases the variation in value & NS & Reject \\
\hline H6: & Better written confirmation significantly decreases the variation in value & .196 & Accept \\
\hline H7: & Appropriate valuer conduct significantly decreases the variation in value & NS & RS \\
\hline H8: & Better enforcement significantly decreases the variation in value & NS & Reject \\
\hline H9: & Appropriate disclosure significantly decreases the variation in value & NS & Reject \\
\hline H10: & Less conflict of interest significantly decreases the variation in value & .298 & Accept \\
\hline H11: & Less client influence significantly decreases the variation in value & .205 & Accept \\
\hline H12: & More investor confidence significantly decreases the variation in value & &
\end{tabular}

Table 5.5 summarizes the significant differences of the 12 standards on variation in value. There were total of 4 positive significant differences and 8 show no significant difference. Complete report, Lower Client Influence, Investor Confidence and Written Confirmation were positively influence on Variation in Value. However, the Role of Valuer was negatively influence on Variation in Value due to the valuer conducting the valuation relies more on their personal opinions than the requirement standards or principles also, best practice and external factors influence more. 


\section{Summary of Hypothesis: Increase Investor Confidence}

Table 5.6 Summary of Hypothesis: Increase Investor Confidence

\begin{tabular}{|l|l|c|c|}
\hline H13: & Better valuation purpose significantly increase investor confidence & .162 & NS \\
\hline H14: & Better complete report significantly increase investor confidence & -.262 & Reject Less Confidence \\
\hline H15: & Better scope and assumptions significantly increase investor confidence & -.161 & Reject Less Confidence \\
\hline H16: & Better role of valuer significantly increase investor confidence & .226 & Accept \\
\hline H17: & Better valuer qualification significantly increase investor confidence & NS & Reject \\
\hline H18: & Better written confirmation significantly increase investor confidence & .144 & Accept \\
\hline H19: & Appropriate valuer conduct significantly increase investor confidence & NS & Reject \\
\hline H20: & Better enforcement significantly increase investor confidence & .142 & Reject \\
\hline H21: & Appropriate disclosure significantly increase investor confidence & NS & Accept \\
\hline H23: & Less conflict of interest significantly increase investor confidence & .269 & Reject \\
\hline H24: & Less client influence significantly increase investor confidence & Accept \\
\hline H22: & Less variation in value significantly increase investor confidence & &
\end{tabular}

Table 5.6 summarizes the significant differences of the 12 impacts on investor confidence. There were total of 5 positive significant differences and 7 show no significant difference. Valuation Purpose, Valuer Qualification, Valuer Conduct, Level of Conflict of Interest and Level of Variation in Value were positively influence on increase Investor Confidence. However, scope and assumptions and role of valuer negatively impact investor confidence due to external factors such as social, economy, and politic pressures that are not included or mentioned in the conditions and assumptions stated in the valuation report. For the role of valuer, investor confidence more concerned with less variation in value and best practice.

\section{Conclusion}

The findings of the regression results reveal that from the twelve independent variables that impact Variation in Value and Investor Confidence there were five significant variables that decrease Variation in Value and seven significant variables that increase Investor Confidence. Complete Report was the strongest influence on variation in value with a .383 beta (compare Yiu,, 2006; Hager and Lord, 1985; Haper, 2008; Levy and Schuck, 1999; Joslin, 2005; Bretten and Wyatt, 2001). Variables under Complete Report were found to have influence on variation in value. For investor confidence, Variation in Value was the strongest influence (beta .269) (compare Kauko and Amato, 2009). Interestingly, Role of Valuer was found to impact both. When included as influential factors investor confidence results in less variation in value. Similarly, less variation in value (as an impact) influences investor confidence.

\section{References}

[1]. Adair, A. and Hutchison, N. (2005), "The reporting of risk in real estate appraisal property risk scoring”, Journal of Property Investment and Finance, Vol.23 No. 3, pp. 254268.

[2]. Amidu, A., R. and Aluko, B., T. (2007) "Client Influence on Valuation: Perceptual Analysis of the Driving Factors", International Journal of Strategic Property Management, pp. 11, 77-89.

[3]. Amidu, A., R., and Aliko, B., T. (2007), “Client Influence in Residential Property Valuations: An Empirical study”, Property Management, Vol.25 No.5, pp. 447- 461.

[4]. Avittey, J., Gyamfi-Yeboah, F. and Gambrah, A. (2006), "Valuers: Value Investors or Assessors", Valuations and quantity surveying, Promoting land administration and good governance $5^{\text {th }}$ FIG Regional Conference, Accra, Ghana, 8-11 March 2006, (accessed 10 December 2010).

[5]. Babawale, G. K. and Omirin, M. (2012) "An assessment of the relative impact of factors influencing inaccuracy in valuation", International Journal of Housing Markets and Babawale, G. K. and Omirin, M. (2012) "An assessment of the relative impact of factors influencing inaccuracy in valuation", International Journal of Housing Markets and
Analysis, Vol. 5, No. 2, pp.145 - 160.

[6]. Bank of Thailand. (2010), "Net NPLs Outstanding", available at http://www2.bot.or.th/statistics/ReportPage.aspx?reportID=428\&language=eng. (accessed 24 June 2010).

[7]. Baum, A., Crosby, N., Gallimore, P., McAllister, P., and Gray, A. (2000), "The influence of valuers and valuations on the workings of the commercial property investment market", Reading and Nottingham Trent Universities.

[8]. Brett, M. (2010), "Valuation Standards for the Global Market; Thailand - how valuation failures contributed to financial crisis", available at http://www.rics.org/site/download_feed.aspx?fileID=3540\&fileExtension=PDF (accessed 28 February 2010).

[9]. Bretten, J. and Wyatt, P. (2001), "Variance in commercial property valuations for lending purposes: an empirical study", Journal of Property Investment and Finance, Vol. 19 No. 3, pp. 267-282.

[10]. Bretten, J. and Wyatt, P. (2002), "Variance in Property Valuations for Commercial Lending", Royal Institutions of Chartered Surveyors, RICS Research Papers, pp. 4-9.

[11]. Business and Social Sciences Review (BSSR). (2011), Vol.1 No.3, available at http://www.bssreview.org/volume/vol1-no3-Sep-2011.pdf\#page=4 (accessed 08 November 2011)

[12]. Cao, J., A. (2009), "Developmental state, property-led growth and property investment risks in China", Journal of Property Investment and Finance, Vol. 27 No. 2 , pp.162 -179.

[13]. Chang, N., C. (2004), "A Study of Real Estate Valuation Behavior-An Application of Behavior Theory", Master dissertation of Taipei University.

[14]. Chen, F., Y. and Yu, S., M. (2009), "Client Influence on Valuation: Does Language Matter?, A comparative Analysis between Taiwan and Singapore", Journal of Property Investment and Finance, vol. 21, No.1, pp. 25-41.

[15]. Dominguez, L., R., Alvarez, I., G. and Sanchez, I., M., G. (2009), “Corporate Governance and Codes of Ethics”, Journal of Business Ethics, pp. 187-202.

[16]. Farrelly, K. and Sanderson, B. (2005), "Modeling regime shifts in the city of London office rental cycle", Journal of Property Research, Vol.22 No. 4, pp.325-344.

[17]. Forsythe Appraisals (2008), "Forsythe Appraisals Says New Appraisal Agreement with Fannie Mae and Freddie Mac Will Help Restore Consumer Confidence in Home Market", Real Estate and Investment Week, Atlanta, p. 31. (accessed 22 June 2009).

[18]. French, N. (2011). "Professional Standards: RICS Valuer Registration Scheme", Journal of Property Investment and Finance, vol. 29, No.4/5, pp. 582-587.

[19]. Galiniene, B., M. and Deveikis, S. (2005), "The Professional and Ethical Potential of Lithuania Property Valuers", International Journal of strategic Property Management, Vol. 9 No.43, p.50
Galiniene, B., Meveikis, S. (2005), "The Professional and Ethical Potential of Lithuania Property Valuers", International Journal of strategic Prope

[20]. Gallimore, P. (1994), "Aspects of information processing in valuation judgement and choice”, Journal of Property Research, Vol. 11 No. 2 pp 97-110.

[21]. Gallimore, P. (1996), "Confirmation bias in the valuation process: a test for corroborating evidence", Journal of Property Research, Vol. 13 No. 4 pp261-73

[22]. Gallimore, P. and Gray, A. (2002), "The Role of Investor Sentiment in Property Investment Decisions", Journal of Property Research, Vol. 19 No.2, pp 111-20.

[23]. Gilbertson, B. and Preston, D. (2005), “A vision for valuation”, Journal of Property Investmentand Finance, Vol. 23 No. 2, pp. 123-140. 
[24]. Gwin, C., R. and Maxam, C., L. (2002), "Why do Real Estate Appraisals Nearly Always Equal Offer Price? A Theoretical Justification”, Journal of Property Investment and Finance, pp.242-53.

[25]. Hager, D., P. and Lord, D., J. (1985), “The Property Market, Property Valuations and Property Performance Measurement”, Journal of the Institute of Actuaries, pp 19-60

[26]. Harper, D. (2008), "Valuation of Hotels for Investors", Estates Gazette Title, pp. 1-197.

[27]. Hordijk, A., Nelisse, P., Koerhuis-Gritter, L. (2011) "European valuation practices: how to compare valuations across borders? Initial findings", Journal of Property Investment and Finance, Vol. 29 Iss: 4/5, pp. $575-581$

[28]. Hummel, A. (2008), "The Property Valuation Professional: Providing Local Expertise, Allowing for Credible Global Financial Decisions", available at http://www.appraisalfoundation.org/s_appraisal/bin.asp?CID=321\&DID=1045\&DOC=FILE.PDF. (accessed 11 December 2008). International Valuation Standards Committee (IVSC). (2007), United Kingdom, London, $8^{\text {th }}$ ed.

[30]. International Valuation Standards Committee (IVSC). (2008), United Kingdom, available at http://www.ivsc.org. (accessed 14 December 2008)

[31]. Jaccard, J. \& R. Turrisi (2003). "Interaction Effects in Multiple Regression”, Sage.

[32]. Joslin, A. (2005), “An investigation into the expression of uncertainty in property valuations", Journal of Property Investment and Finance, Vol.23 No. 3, pp. $269-285$.

[33]. Kauko, T. and Amato, M. (2009), "Mass Appraisal Methods: An International Perspective for Property Valuers”, International Journal of Strategic Property Management, pp 359-364.

[34]. Layne, D. (2002), “The state of valuation in Thailand”, The Appraisal Journal, Vol.70 No. 3, available at www.thaiappraisal.org/english/thairealestate/tre_preview.php, (accessed 16 February 2010).

[35]. Levy, D. and Schuck, E. (2005), "The Influence of Clients on Valuations: the clients'

[36]. Perspective", Journal of Property Investment and Finance, Vol.23 No.2, pp.182-201

[37]. Levy, D. and Schuck, E. (1999), "The Influence of clients on Valuations", Journal of Property Investment and Finance, Vol. 17 No. 4.

[38]. Lin, T., C. and Chang, H., Y. (2012) "How do appraisers absorb market information in property valuation?: Some experimental evidence", Journal of Property Management, Vol. 30, No 2, pp.190 - 206.

[39]. Lorenz, D., Trück, S. and Lützkendorf, T. (2006), "Addressing risk and uncertainty in property valuations: a viewpoint from Germany", Journal of Property Investment and Finance, Vol. 24 No 5, pp.400- 433

[40]. Mansfield, J., R. (2009), "The valuation of sustainable freehold property: a CRE perspective", Journal of Corporate Real Estate, Vol. 11 No 2, pp.91-105.

[41]. Mansfield, J., R. and Royston, P, J. (2007), “Aspect of Valuation practice in Central and Eastern European Economics”, Journal of Property Management, Vol. 25, No. 2, pp. 150-163.

[42]. Miller, P. (2011), "New Appraisal Standards to Impact Mortgage Rates". Available at http://blog.hsh.com/index.php/2011/09/new-appraisal-standards-to-impact-mortgagerates/ Retrieved February 16, 2011

[43]. Ojo, O. (2009), “Corporate Social Responsibility: The Estate Surveyors and Valuers' Perspective”, p. 233.

[44]. Pacharavanich, P. and Rossini, P. (2001), "Examining the potential for the development of computerised mass appraisal in Thailand", Pacific Rim Real Estate Society Conference, 21-24 January 2001, Adelaide, Australia, (accessed 1 February 2011).

[45]. Pattanapongpiboon, K. (2009), "The Valuers Association pushes the publish of Act.", Real Estate, available at www.bangkokbiznews.com/home/news/property/property/2009/02/09/news_14302.php (accessed 24 February 2010).

[46]. Razali, M., N. and Adnan, Y., M. (2012) "Transparency in Malaysian property companies", Journal of Property Management, Vol. 30, No.5, pp.398 - 415

[47]. Rothacker, R. (2008), "Home appraisal overhaul draws fire", McClatchy - Tribune Business News, Washington.

[48]. Royal Institution of Chartered Surveyors (RICS). (2010), available at http://www.rics.org/site/scripts/documents.aspx?categoryID=190, (accessed 18 September 2010).

[49]. Rushmore, S. (1993), "Ethics in hotel appraising", The Appraisal Journal, Vol. 61 No. 3, pp. 357-63.

[50]. Smith, S. (2002), "Predatory Lending, mortgage Fraud, and Client Pressures", The

[51]. Appraisal Journal, pp. 200-213.

[52]. Smolen, G., E. and Hambleton D., C. (1997), "Is the Real Estate Appraiser's Role too Much to Expect". The Appraisal Journal, Vol. 65 No.1, 9-17.

[53]. Sui, T., G. (2001), "Valuation Practice in Malaysia", Thai Appraisal Foundation, available at http://www.thaiappraisal.org/english/international/re07.htm. (accessed 10 Sui, T., G. (2001), "Valuation Practice in Malaysia", Thai Appraisal Foundation, available at http://www.thaiappraisal.org/english/international/re07.htm. (accessed 10
December 2010).

[54]. Thapanachai, S. (2008), "Thai investors must be cautious: Valuation crucial for property purchases", Mcclatchy-Tribune Business News, Washington, (accessed 16 December 2008).

[55]. Thai Valuers Association. (2010), "Thai Valuers Journal, Vol 35, January-March 2010", available at http://www.tva.or.th/more_news.php?cid=23, (accessed 1 December 2012).

[56]. The Board of Valuers, Appraisers and Estate Agents Malaysia. (2010), available at http://www.lppeh.gov.my/codeofconduct.html, (accessed 10 December 2010).

[57]. The Valuers Association of Thailand (VAT). (2008), available at http://www.vat.or.th/main/catalog.php?idp=74, (accessed 14 December 2009).

[58]. The Valuers Association of Thailand (VAT). (2011), "List of qualified valuation companies as of 8 October 2012", available at http://www.vat.or.th/upload/assessment_file/file_news1d17y2012.pdf, (accessed 25 November 2012).

[59]. Thorne, C. (2012) "Valuation: the professional challenge", Journal of Property Investment and Finance, Vol. 30, No. 4.

[60]. U.S. Attorney's Office (2010), "Real Estate Appraiser Sentenced to Three Years in Prison in Mortgage Fraud Scheme That Led to \$46 Million in Losses", available at http://www.fbi.gov/losangeles/press-releases/2010/la012910a.htm, (accessed 10 November 2011).

[61]. Vitell, S., J. and Hidalgo, E., R. (2006), "The Impact of Corporate Ethical Values and Enforcement of Ethical Codes on the Perceived Importance of Ethics in Business: A Comparison of US and Spanish Managers", Journal of Business Ethics, pp. 31-43.

[62]. Yiu, C., Y., Tang, B., S., Chiang, Y., H. and Choy, L., H., T. (2006), “Alternative Theories of Appraisal Bias” Journal of Real Estate Literature, Vol. 14, No, 3.

[63]. Warren-Myers, G. and Heywood, C. (2010), "The use of heuristics in valuation practice: implications in a changing market", in ERES 2010: Proceedings of the 17th ERES Conference, SDA Bocconi School of Management, Milan, Italy.

[64]. Whipple, R.T.M. (1991), "Valuations for Commercial Rent Review Purposes Procedural Guidelines and Other Commentary", Journal of Property Valuation and Investment, Vol. 9 No2, pp. $159-174$ 